\title{
The Impact of Indonesia's 2019 Presidential Campaign on the Human Rights Movement: Narrow Solidarity versus Affinity
}

\author{
Saskia E. Wieringa \\ University of Amsterdam, Amsterdam, The Netherlands \\ Email: s.e.wieringa@uva.nl
}

How to cite this paper: Wieringa, S. E. (2020). The Impact of Indonesia's 2019 Presidential Campaign on the Human Rights Movement: Narrow Solidarity versus Affinity. Open Journal of Political Science, 10, 705-731.

https://doi.org/10.4236/ojps.2020.104041

Received: July 6, 2020

Accepted: October 17, 2020

Published: October 20, 2020

Copyright $\odot 2020$ by author(s) and Scientific Research Publishing Inc. This work is licensed under the Creative Commons Attribution International License (CC BY 4.0).

http://creativecommons.org/licenses/by/4.0/

\section{(c) (i) Open Access}

\begin{abstract}
In the April 2019 elections in Indonesia, the incumbent president, Mr. Joko Widodo, was pitched against former general Mr. Prabowo Subianto. Mr. Widodo won his first term with a strong human rights agenda that was supported by thousands of human rights activists. In his 2019 campaign, the focus was on the country's economic development. During this campaign, authoritarian tools were widely used to stifle criticism of the incumbent. The human rights movement became strongly polarized between adherents of the two presidential candidates. Both camps waged a fierce social media war in which hoaxes and slander were spread. The political blocs quickly reconciled after the elections, striving for a politics based on consensus. Army factions and Muslim parties that had supported the different sides also soon closed ranks. However, the fracturing of the human rights movement into two opposing camps remained also after the elections. This led to its enervation in relation to several illiberal immediate post-election reforms. In this article, I focus on four cases to analyse the divisive dynamics within the human rights movement. These are the post-October 1965 genocide, the weakening of the Anti-Corruption Commission, the revision of the Criminal Code, and the Anti-Sexual Violence Bill. Problems of solidarity politics will be pointed out. I will examine some hoaxes in social media as they are informative of the discourse in this heated period. The human rights debate between the two candidates on 17 January 2019 will also be discussed. Although external factors such as the growing influence of conservative majoritarian Islam played a major role in the inability of the human rights movement to stop the weakening of the Anti-Corruption Commission, and the deliberations on the revision of the Criminal Code, I focus here on the fragmentation and polarization of the movement and the failure of the participants to engage in affinity politics based on shared interests.
\end{abstract}




\section{Keywords}

Indonesian 2019 Elections, Human Rights, 1965 Genocide, Anti-Corruption Commission, Sexual Violence Bill, Criminal Code, Social Media, Solidarity, Affinity

\section{Introduction}

In April 2019, elections were held in Indonesia. Lawmakers for the national parliament ${ }^{1}$ and members of various national and regional bodies could be chosen, as well as a new president. The incumbent, Mr. Joko Widodo, popularly called Jokowi, was challenged by former general Mr. Prabowo Subianto, usually referred to by only his first name. Jokowi won his first term in 2014 with a strong human rights agenda which was supported by thousands of human rights activists. However in the course of his tenure it soon became clear that human rights issues were disregarded (McGregor \& Setiawan, 2019). In Jokowi's 2019 campaign, the focus was on the country's economic development. The neglect of human rights issues is a marker of the country's slide towards an illiberal democracy which had already set in before his first term of office (Bourchier, 2015; Hadiz, 2017). Two decades after the fall of the military dictator Suharto in 1998, the hopes of human rights activists, such as an end to corruption and the settlement of past human rights violations have faded. During the 2019 campaign, authoritarian tools were widely used to stifle criticism of the incumbent. Other factors that contributed to the tensions in society include the growing nationalism and the Islamization of society, leading to an increasing conservatism in relation to issues of gender and sexual rights (Butt, 2018).

In this article, I use the term human rights movement rather broadly, referring to the broad and divergent conglomeration of NGOs that deal with protection of the rights of women, sexual and religious minorities and other oppressed social groups. The movement consists of the wide variety of legal and women's aid bureaus, organizations that support victims of human rights, fight against the stigma survivors face and which denounce the impunity of the perpetrators. The older NGOs have roots in the period before the democratic opening of society in $1998^{2}$. Environmental and labour activists also belong to this wider human rights movement but they are not the topic of discussion here ${ }^{3}$.

The 2019 campaign between the two rivals was bitter. Deep rifts in civil society became apparent. The human rights movement became strongly polarized between adherents of the two presidential candidates. Both camps waged a fierce social media war in which hoaxes were spread and individuals defiled.

${ }^{1}$ The national parliament is called Dewan Perwakilan Rakyat, People's Representatives' Council. I will refer to its members as parliamentarians, lawmakers or representatives.

${ }^{2}$ See for a discussion on human rights movements Tsutsui and Wotipka (2004).

${ }^{3}$ They do have major concerns though, such as the Mining Law which was passed early 2020 and the draft Omnibus Law on Job Creation. 
After the elections, the political blocs quickly reconciled and Prabowo joined the cabinet of his former rival. The political culture of the country tends towards creating a consensus, in which economic and political differences are glossed over (Duile \& Bens, 2017). Army factions and Muslim parties which had supported the different sides also soon closed ranks. With the political dice cast, they scrambled to defend their interests as best as possible. However, the fracturing of the human rights movement into two opposing camps remained. The mechanisms of this split and its social and political impact are the focus of this article. I argue that one of the consequences of this development is its enervation in relation to the illiberal immediate post-election reforms, such as the revision of the Anti-Corruption Law, the deliberations on the Criminal Code and the failure of the adaptation of the Anti-Sexual Violence Bill. External factors also played a major role, the suppression of voices of dissent to the ruling elite and particularly of the president himself, the growth of majoritarian religious conservatism, and a form of aggressive nationalism. These topics are discussed elsewhere (Bourchier, 2019; Buehler, 2016; Hadiz, 2017; Heryanto, 2006; Mietzner, 2015). In this article, I focus on four cases to analyse the dynamics within the human rights movement. These are the post-October 1965 mass murders, the weakening of the Anti-Corruption Commission, the deliberations on the revision of the Criminal Code and its impact on the LGBT movement and lastly the Anti-Sexual Violence Bill. I will discuss some hoaxes in social media as they are informative of the discourse in this heated period. The human rights debate between the two candidates on 17 January 2019 will also be examined. I argue that the consensual nature of the political climate extends to the human rights movement, translating breaches of this consensus as treachery, reflecting the alleged low morality of adversaries. Instead of this narrow politics of solidarity, I posit a more flexible and fluid politics of affinity, based on shared political interests.

\section{Methodology}

This article is based on an eclectic mix of qualitative methods. As a participant and bystander I witnessed the dynamics discussed at close hand. I am the chair of the Foundation International People's Tribunal on Mass Crimes against Humanity after 1965 (IPT 1965) ${ }^{4}$. I have been doing research on and been a participant in the Indonesian women's movement and the LBT movement for over 30 years. I attended several meetings on human rights issues in the years 2017-2019, watched the anti-Ahok mass demonstrations in 2016, the presidential debates and their rallies on national TV and collected thousands of pages of newspaper and journal articles on the developments discussed here. I am also a member of several social media platforms on which topics discussed here appeared. Methods used thus include interpretive, ethnographic and critical analysis of my sources $(\mathrm{McNabb}, 2015)$ in which participant observation is supported by the

${ }^{4}$ We organized the People's Tribunal on 1965 in The Hague, 2015 (Wieringa, Melvin, \& Pohlman, 2019). 
analysis of secondary sources (Jorgensen, 2015).

\section{Political and Historical Background}

To understand the background of the present-day human rights movement I will discuss the events of 1965, the New Order and the resistance it engineered as well as the two sexual moral panics that inform much of today's political climate.

Since 1998, when the authoritarian regime of general Suharto, called the New Order, was toppled after mass protests, Indonesia has had a committed and sophisticated human and women's rights movement. The importance of upholding human rights is widely recognised among the progressive intellectual elite. Endy Bayuni, the chief editor of the Jakarta Post, reminded his readership in January 2019 that "one of the reasons why the Suharto regime collapsed in 1998 was because of the endless violations of human rights throughout his reign, going back to the killing and jailing of millions of people in the wake of the abortive 1965 coup" . Many observers however have noted the speed of Indonesia's slide into an illiberal democracy (Aspinall \& Mietzner, 2010; Bourchier, 2015; Wilson, 2015a). Reminiscent of the New Order is the continued wide deployment of vigilantism, aimed at religious and sexual minorities (Bakker, 2016; Wilson, 2010, 2015b).

On paper, respect for human rights is firmly enshrined. Indonesia has ratified eight core international conventions, including CEDAW, popularly called the Women's Convention (in 1984) and the ICCPR, the International Covenant on Civil and Political Rights (in 2006) ${ }^{6}$. After the 2002 revisions of the constitution, respect for human rights is included in the Chapter X. Article $28 \mathrm{D}(1)$ reads that "each person has the right to recognition, security, protection and certainty under the law that shall be just, and treat everybody as equal under the law". Article $28 \mathrm{e}(3)$ stipulates that "each person has the right to freely associate, assemble, and express his opinions". Freedom of thought and conscience is guaranteed in art 28I(1). Though the constitution is secular, in practice the human rights it guarantees are circumscribed by an emphasis on the first clause of the preamble to the constitution, the Pancasila (Five Pillars), which states that Indonesia adheres to belief in one God (ignoring that it has a sizeable polytheistic Hindu minority and many adherents of nature religions). This statement is often misused by Muslim fundamentalists, accusing those who do not support a sharia-based state as anti-religion and anti-nation. The other pillars of the Pancasila refer to humanity, Indonesian unity, democracy and social justice, but these are downplayed by Muslim right wing groups, as well as by the army ${ }^{7}$.

${ }^{5}$ The role of general Suharto in this affair has never become clear, and some suggest that his involvement has been so effective that it might be better to speak of the start of a very successful coup, namely the replacement of President Sukarno by General Suharto. See for this debate Wieringa and Katjasungkana (2018).

${ }^{6}$ https://tbinternet.ohchr.org/_layouts/15/TreatyBodyExternal/Treaty.aspx?CountryID=80\&Lang=EN CEDAW is short for Convention on the Elimination of All Forms of Discrimination. Accessed 16 March 2020.

${ }^{7}$ See for a discussion on the working of propaganda in Indonesian history Wieringa and Katjasungkana, 2018. 


\subsection{Moral Panics}

Anti-communism and more recently homophobia are two important factors which help to engineer a broad consensus among dominant political actors of Indonesia's character as a nation dominated by Islam. These are fuelled by two sexual moral panics. The first panic was created by general Suharto after the action of the so called 30 September Movement in the early morning of October 1, 1965. Six generals and one lieutenant were abducted and killed. General Suharto who was not abducted, was informed of this action beforehand. He blamed the Indonesian Communist Party (PKI) for this affair, and created a black propaganda campaign in which girls belonging to Gerwani, the women's organization associated with the PKI, was accused of having castrated and killed the generals on the training field. This sexual slander helped justify the mass murders which general Suharto organized, and helped to incite militias to assist the military. It is commonly thought that between half a million and one million people were murdered or forcibly disappeared. Hundreds of thousands were detained, many of them in slave labour camps (Cribb, 1991; IPT 1965, 2017). Over the following months Suharto side-lined Sukarno and had himself promoted to President (Melvin, 2018; Robinson, 2018; Roosa, 2006; Wieringa \& Katjasungkana, 2018).

The influence of the first sexual moral panic, the slander about the girls of Gerwani, was long lasting (Wieringa, 2002, 2003). Its effects are felt even now (Wieringa \& Katjasungkana, 2018). During the New Order any opposition to General Suharto's rule was brutally oppressed. Yet some resistance appeared. The regime insisted on holding regular elections, which were tightly controlled (Antlöv \& Cederroth, 2004). Voting was obligatory. Those who wished to demonstrate their protest marked the white (putih) section of the ballot paper, making it invalid. Thus the term golput (golongan putih, the white group) was coined $^{8}$. Another form of protest rose from Islamist organisations, which started dakwah (proselytizing) groups particularly in universities. From the 1980s onwards, these groups became more influential (Buehler, 2016; Kersten, 2015). Thirdly the first human rights groups and feminist organizations were established which had to maneuver very carefully in the oppressive political climate.

Spearheaded by feminists who posed as housewives hard hit by the 1997 monetary crisis (how can the self-styled Father of Development fail to provide milk for the country's babies?), massive protests of students and other activists led to the downfall of the dictator in 1998 (SIP, 1999; Hadiz, 2000). The democratic opening of society that followed is called the Reform period (Nyman, 2006). Both human rights activists and Islamist groups made wide use of the new rights they enjoyed, freedom of speech and organization. One of the major achievements of this period is the establishment of a strong Anti-Corruption Commission.

The second moral panic emerged in late 2015, when a wave of homophobic statements of important political and academic leaders hit the press (Katjasungka-

${ }^{8}$ It is also explained as a bastardization of Golkar, the name of Suharto's party. 
na \& Wieringa, 2016). This crippled the sexual rights movement in Indonesia (Wieringa, 2019a, 2019b).

\subsection{Political Islam}

With the left movement destroyed after 1965, Indonesia does not know a political climate in which a healthy form of what Mouffe calls "conflictual consensus" operates. Instead, as Duile and Bens (2017), following her analysis, maintain, a broad consensus operates among all political parties, consisting of ideas on Islam and the nation/the people. Although neither concepts are clearly spelled out they have great mobilizing power. Conservative Islamic organizations, though differing on many details, have gradually come to dominate the debate on what Islam means. The power of political Islam, after decades of dakwah, became manifest in the mass protests against the popular Christian and ethnically Chinese Governor of Jakarta, Ahok (Basuki Tjahaja Purnama), in late 2016 and early 2017. On the basis of a manipulated video fragment he was accused of blasphemy against Islam. On November 4, 2016 a first mass demonstration was held (the so called 411 action). On December 2, an even larger and more aggressive demonstration was held in Jakarta and in other cities across the nation (the 212 action). This mass mobilization created such massive anti-Ahok sentiments that he was defeated in the gubernatorial electoral campaign in 2017 by Anies Baswedan (Nawab, Osman, \& Waikar, 2018). Ultimately he was sentenced to a two-year jail term (Kersten, 2015). Since then the 212 movement, a loose conglomeration of far-right Islamist groups, including the Front Pembela Islam (FPI, Islamic Defenders Front), Hizbut Tahrir Indonesia (HTI, Party of Liberation), Gerakan Nasional Pengawal Fatwa-Majelis Ulama Indonesia (GNPF-MUI, National Movement for Guiding the Fatwa of Majelis Ulama Indonesia), and Forum Umat Islam (FUI, Islamic Community Forum) has become an electoral force, supporting the candidacy of Prabowo. Two other issues can be observed. In the first place the passivity of Jokowi, who did not support his erstwhile ally. And secondly the victory of Anies Baswedan, who became the next Governor of Jakarta. This non-party politician was a respected Minister of Education in Jokowi's first Cabinet (2014-2016).

Though Islamist parties form only a minority in parliament, they mobilized in the extra-parliamentary space which has become the main avenue for debates on morality and Islamic values (Kersten, 2015). Through decades of slowly infiltrating the educational sectors, and many mosques (via the doctrine of tarbiyah, continued education) they have managed to normalize sectarian intolerant Islamism. Though neither progressive nor conservative Muslims adhere to a unified common vision of what constitutes Muslim values, the Islamist groups managed to create an atmosphere in which accusations of being "anti-Islam" are being hurled indiscriminately. Parliamentarians, particularly from secular parties and the public at large try to portray an image of themselves as "good Muslims", and promoting sharia-based morality laws are part of that package 
(Buehler, 2016). This is not a new issue in Indonesia. In fact, Islamist terrorism has been a constant threat, and at times erupted in very bloody conflicts, particularly in the areas that voted for Prabowo (Wieringa \& Katjasungkana, 2018). Recently the notorious Muslim militia FPI has been promoting a NKRI Sharia (Negara Kesatuan Republik Indonesia) a Unitary Indonesian State based on sharia law (Tim Detikcom, 2019) ${ }^{9}$.

This conservative religious trend has been particularly felt in the areas of gender, sexuality and morality. Hundreds of regional regulations have been promulgated which stipulate dress codes for women, and attempt to regulate people's sexual conduct consistent with sharia laws (Van Dijk \& Kaptein, 2016; Buehler, 2016; Fauzi, 2016; Kersten, 2015; Katjasungkana \& Wieringa, 2016).

The curbing of civil rights already evident during Jokowi's first term became even more pronounced during the 2019 electoral campaign. The abuse of the 1965 Blasphemy Law $^{10}$ and the 2008 Electronic Information and Transactions law (ITE) Law under which even WhatsApp chats can lead to one's arrest is a formidable weapon (Sugiharti, 2018). Other legal ways to criminalize people are the Articles 106 and 110 of the Criminal Code, which refer to crimes against security of the state, especially makar, (treason). This label is widely placed on adversaries of Jokowi. Among those convicted under these laws is the popular singer and Jokowi-critic Ahmad Dhani ${ }^{11}$. During the first years of the Reform era, there was only one case in which the treason accusation was used, that of Papuan independence activist Filep Karma ${ }^{12}$.

The Indonesian political landscape is essentially transactional, based on the circulation of power and resources among an elite consisting of business tycoons, military and political leaders (Aspinall \& Mietzner, 2010). Aspinall and Berenschot (2019) point to the high expenses of the election campaigns which inevitably leads to patronage via a system of "free-wheeling clientelism". This economic, political, military and religious elite operates on the basis of a keen insight in how to advance their own interests. Ideological conflicts are veiled under the broad blanket of a discourse on the Indonesian nation as being characterized by Islamic morality, while underneath bitter conflicts rage on power and resources.

\subsection{The Presidential Candidates and Human Rights}

During the electoral campaign the president defended his record, showcasing progress in infrastructure. Prabowo exposed the many shortcomings in Jokowi's

\footnotetext{
${ }^{9}$ See also the collection of essays edited by Arismunandar (2019) for a discussion on the theme.

${ }^{10}$ The Blasphemy Law is incorporated in the Criminal Code.

${ }^{11}$ News Desk The Jakarta Post (2019a).

https://www.thejakartapost.com/news/2019/12/30/ahmad-dhani-walks-free-after-serving-11-month s-for-hate-speech.html Jakarta/Mon, December 30, 2019. He was sentenced for tweeting: "Anyone who supports the blasphemer is scum and deserves to be spat in the face." With the blasphemer he meant Ahok. Later he was sentenced again for calling political rivals of Gerindra "idiots".

${ }^{12} \mathrm{He}$ was sentenced to 15 years in prison for raising the Papuan independence flag, the Morning Star, in 2004 .
} 
presidency, particularly in the economic field, promising to address them. Jokowi had cobbled together a large coalition of nine political parties, including the two largest winners in 2014, the Indonesian Democratic Party of Struggle (PDI-P) and Golkar, two Muslim parties, the Islamist United Development Party (PPP) and the moderate National Awakening Party (PKB). Prabowo's coalition was smaller, consisting of his own Gerindra, former president Yudhoyono's Democratic Party and two Islamist parties, the Prosperous Justice Party (PKS), and the National Mandate Party (PAN) ${ }^{13}$.

Due to his promise to deal with Indonesia's ugly record of past human rights violations, such as the 1965-1968 genocide and other crimes against humanity including those committed in Aceh, Papua and East Timor, Jokowi had attracted an enthusiastic following of human rights defenders in 2014. Prabowo was widely accused of human rights violations and was supported by conservative Muslim groups. Both candidates had strong support of various army factions.

On January 17, 2019 the first presidential debate was held; it focused on human rights. Jokowi tried to capitalize on his clean human rights record "We are not dictators or authoritarians. We do not have a track record of human rights violations, violence or corruption" (Sapiie \& Ramadhani, 2019). But in this self-declared clean record he makes no mention of his broken promises. In the Nawacita, his nine-point programme at the start of his first presidency, Jokowi pledged to resolve at least seven cases, including the 1965-1968 mass killings of members of communist organisations and staunch supporters of President Sukarno. The only progress he has made is one single meeting with the survivors and families of the victims of past human rights abuses who regularly participate in a weekly silent protest in front of the presidential palace known as Kamisan (Meeting on Thursday). The closed meeting in May 2018 was the first time that Kamisan participants had met with any president since they embarked on their quest in January 2007 (News Desk The Jakarta Post, 2018). During his term in office, other cases occurred which also remained unresolved, such as the acid attack on a prominent investigator of the Anti-Corruption Commission (KPK) Novel Baswedan in April 2017. Jokowi had also vowed to strengthen the KPK.

Instead of addressing the 1965-1968 genocide, Jokowi did not criticize the army when they accused the Communist Party of Indonesia (PKI) and the LGBT community of waging "proxy wars" against the Indonesian nation (Wieringa, 2019a; Wieringa \& Katjasungkana, 2018). Ludicrous as these accusations might seem, the hate campaigns against the octogenarian survivors of the 1965 genocide and the LGBT community have led to great suffering. Book raids and disruptions of meetings by vigilante groups contributed to the perpetuation of New Order-style terror and fear (Wieringa \& Katjasungkana, 2018).

Another indication of Jokowi's disregard for human rights was his Presidential Letter on Mass Organisations (No. 2/2017) ${ }^{14}$. This allowed him to ban with-

\footnotetext{
${ }^{13}$ Two smaller parties in this coalition (Berkarya and Garuda) did not pass the electoral threshold.

${ }^{14}$ This presidential letter was subsequently endorsed by parliament.
} 
out due legal process the fundamentalist group HTI which rejects the Indonesian state and calls for a caliphate (Wibisono, 2018). Many human rights activists protested. Indonesia counts around 400.000 mass organizations which might likewise be affected when the mood strikes the president.

Prabowo Subianto has been widely accused of committing major human rights violations when he served in the military. He was implicated in the kidnapping of pro-democracy activists between 1997 and 1998, some of whom disappeared. Prabowo however claims that the activists he abducted, on allegations some of them had been preparing a bomb, all returned home. This is corroborated by a recent report by Raditya (2019). Yet under whose responsibility other activists were made to "disappear" remains unclear.

He has also been accused of instigating a mass killing in East Timor. The report on human rights violations in East Timor during the independence war with Indonesia, points to his hand in the killing of hundreds of unarmed civilians in the Kraras area, Viqueque, in $1983^{15}$. This massacre is the greatest act of killing perpetrated by the army since 1965-1968. Again Prabowo has rejected his involvement. His denial is supported by a report from the BBC journalist Alisjahbana (2014), who investigated the massacre. Yet in spite of these reports which exonerate him from these accusations, many questions on the details of these and other operations remain.

Haris Azhar, an influential human rights activist, concluded that Jokowi and Prabowo had similar views on human rights: neither cared about the persecution of religious minorities or of LGBT people, cases of abuse in Papua and the continued stigmatization of victims of the 1965-1966 massacres (Syakriah, 2019). The January 2019 presidential debate on human rights then was a tame affair. Neither candidate directly challenged the other on their records, for fear of being similarly attacked. In subsequent debates, the topic did not feature any more.

\subsection{Hoaxes and Buzzers}

The confrontation between supporters of Jokowi and of Prabowo took place both at the public and the personal level. In the public realm tens of thousands of paid and unpaid people hurled accusations against each other on various social media platforms and spread hoaxes. During the election campaign branding the enemy candidate via social media as a spectre of that which the own camp most despised was widespread. Jokowi was accused of being a crypto communist, Prabowo of harbouring the wish to establish a caliphate. As Jokowi had been unwilling to lift the stigma of communism during his first tenure (Wieringa, 2019a), being called a communist had a great impact. In the summer of 2018, a frustrated Jokowi denied rumours of his secret membership in an alleged clandestine PKI organization. Exasperated he noted that he was born in 1961 while the PKI was destroyed in 1965 . He sarcastically asked if there was a PKI toddlers'

${ }^{15}$ Final report of the Commission for Reception, Truth and Reconciliation in East Timor (CAVR), finalized in 2005 and published in five volumes by Gramedia in 2015. 
division (Wadipalapa, 2019). As Bachari (2019) notes, other themes of the hate speech directed against Jokowi include his alleged support for China ${ }^{16}$.

Hoaxes spread about communists at the time included stories about PKI members killing Islamic scholars. This reinforced Jokowi's anti-Islam image. A video went viral in which three women were shown to spread the hoax that Jokowi if elected would ban the azan (call to prayer) and legalize gay marriage (Coconuts Jakarta, 2019).

An example of a typical anti-Jokowi hoax: on "12 Ramadhan 1440" a WhatsApp message went viral signed by Hadji Ibnu Buang who opined that these elections were not a "celebration of democracy but a conspiracy of the Jokowi regime to abolish the Indonesian state and the state philosophy Pancasila". In condensed form his arguments amount to the following: This is a coup by the PKI, who is hiding behind the elections. Do we leave the state and the Pancasila in the hands of local communists and China? And what will happen when the communists are in power? Religion will be eradicated, Islam will be annihilated, human rights will be abolished. Our heroes will be chased, imprisoned, tortured. The mosques will be closed, the Qur'an prohibited. We will become slaves in our own country, the wealth of our nation will be spent in China. Jokowi and the PKI are traitors of our nation who have stolen the victory from Prabowo. Those in the army with combatant skills should fight now against the supporters of Jokowi. They must be captured or shot. And if you don't fulfill this holy task, give your weapons to the Muslim Youth who are ready to do their duty. We can only choose between living a noble life or dying as a martyr.

The Jokowi camp on the other hand created an atmosphere as if their adversaries were preparing for a coup, and they arrested radical clerics and opposition figures. Pro-government elements deployed Twitter bot networks using fake or stolen profile photos, operated by paid buzzers, amongst others using a method called "hashtag hijacking". They could spread their misinformation undisturbed (Strick \& Syavira, 2019). The supporters of General Prabowo used the arrests of the clerics to strengthen the idea that Islam was under attack. Prabowo supporter Neno Warisman, who founded the "change president" campaign, composed a poem calling on God to help "leaders who have been slandered, ulema who have been imprisoned and warriors who have been obstructed". Midway through the poem it says: "we are worried O Allah That there will be no one to worship You anymore" (Tehusijarana, 2019). Prabowo supporters had to be more careful than the so called Jokowers in using social media to spread slander, as the ITE law was specifically used to target them ${ }^{17}$.

Prabowo had to counter allegations that he wanted to establish a caliphate, once elected. Irritated, in the fourth presidential debate he asked Jokowi to get

${ }^{16}$ Bachari identifies the following themes of hate speech addressed to President Joko Widodo: 1) Joko Widodo's identity, 2) Joko Widodo's relationship with Megawati, 3) Joko Widodo's relationship with the Indonesian Communist Party (PKI), 4) Joko Widodo's support for China, and 5) Joko Widodo's policies that suppressed Islamic groups.

${ }^{17}$ Ardent supporters of Jokowi are often called Jokowers, just as Ahokers are supporters of Ahok. 
his followers to stop promoting that idea, explaining that in his family adherents of many religions are found. "I was born from a Christian womb" (Nathalia, 2019).

During the 2019 campaign, the major battleground was the electoral potential of the large Muslim population. Jokowi, attacked as "anti-Islam"18, reacted by choosing Ma'ruf Amin, the chairman of the ultraconservative Indonesian Ulema Council, as his running mate. He had signed the decree of this Council that led to the charges against Ahok. Prabowo, though leader of the secular party Gerindra, had the support of the fanatical 212 movement $^{19}$.

A former buzzer on the so called Seword social media platform, Khairubbi, gives an insight into how this world of trolls operates ${ }^{20}$. Seword was established by Alifurrahman, during the last years of the presidency of Susilo Bambang Yudhoyono, (whom they criticized) and became well-known during the anti-Ahok demonstrations in 2017 (Gibran, 2017). Khairubbi was an active and successful buzzer on the platform. He was guided by a kakak pembina (guide) who told him to write anything he liked to praise Jokowi, and to criticize Islamic teachings and leaders, and more recently to target Anies Baswedan. Explaining why he withdrew from Seword, Khairubbi explains that he became disillusioned when he realized how poor palm oil and rubber peasants had to survive. Where are the prosperous farmers he was told to write about (Gelora News, 2020)? The kakak pembina who instructed Khairubbi to praise Jokowi in his writings probably belonged to Jokowi's security apparatus ${ }^{21}$.

At the personal level debates among members of the human rights community became toxic. Activists belonging to the other camp were personally slandered, rather than that their ideas were rationally discussed. Supporters of President Jokowi, even if they were aware that he had betrayed his promises to deal with past human rights issues, kept fighting for him. Not so much under the illusion that they might influence his agenda this time, but more to thwart the supporters of Prabowo. In view of Jokowi's well-known love for frogs, his followers were called tadpoles (cebong). They retaliated by calling their adversaries

\footnotetext{
${ }^{18}$ Though Baswedan was initially in the Jokowi camp, as his Minister of Education, the governor of Jakarta has since been relegated to the opposition. This is related both to the way he profited from the anti-Ahok campaign, and as he is seen to be a possible candidate in the 2024 presidential election, in which he might oppose the candidate of Jokowi's patron, Megawati, chair of the PDI-P.

${ }^{19}$ The 212 movement organized the mass protests that brought the popular Christian Chinese governor of Jakarta to jail on trumped up charges of blasphemy. This campaign started in December 2016 and is widely seen as the beginning of large scale identity politics. See for instance Chan (2018). ${ }^{20}$ In popular parlance Seword is also associated with the slang word sewot, or gusar, meaning disgust. Gutter press would be the nearest equivalent in English.

${ }^{21} \mathrm{~A}$ similar case in April 2020 is that of Ravio Patra, whose phone was hacked. He reported this, only to be arrested, as from his hacked phone a call was made for riots to be held. Patra is an independent researcher, critical of the way the government handles the corona crisis. Commenting on this case a Jakarta Post senior editor writes about the dystopian jungle Indonesia's cyberspace has become due to the abuse of the ITE law. He suggests: "We do not know who hacked Ravio's WhatsApp account, but whoever did it has the capability of bypassing the strong security measures used by Ravio, including the two-step verification and a fingerprint. This has raised speculations that the perpetrators have accesses or resources that only state institutions have" (Hermawan, 2020).
} 
bats (kampret), perhaps with the association that these animals are blind (namely to the truth). The two camps fought on all social media. Jokowi's followers showcased his achievements under tags like \#jokowi2periode (Jokowi for two periods). Prabowo's supporters used the hashtag \#jokowibohonglagi (Jokowi lied again), exploiting Jokowi's alleged missteps. Accusations have hurled both ways, with Jokowi's cebong standing accused of being against Islam, and Prabowo's kampret as against the national philosophy Pancasila, for wanting to establish a caliphate ${ }^{22}$.

Disillusioned supporters of Jokowi in the 2014 campaign either stuck with him, as "the lesser evil", pointing to Prabowo's alleged human rights violations. Or they decided to go golput to boycott the elections. As discussed above, this was a popular way of expressing dissent during the New Order period. As a Golput Millennial spokesperson, Saifa El Faruqi, explained, "we are disappointed, the two presidential tickets ... are promoting hostilities and slandering each other so we don't know what program they will pursue" (Tribunnews 2019). Since 2003, abstention is no longer an electoral offense, and golput now also refers to people who consciously abstain. After the elections, it appeared that although the golput phenomenon received wide media attention, the strategy failed, only 2.38 percent of the votes were null or spoilt.

\subsection{The Elections and Their Aftermath: Elite Reconciliation and Flash Legislation}

On May 21, 2019, the Indonesian General Elections Committee announced that on 17 April 55.5 percent had voted for Jokowi, and 44.5 percent for Prabowo. The turnout had been high, over 80 percent, up from 70 percent in 2014. Prabowo did not immediately accept these results, claiming massive electoral fraud had occurred (Sapiie, 2019). Riots broke out; police reacted with excessive force. Eight people were confirmed dead and hundreds wounded and/or arrested (Ghaliya, 2019a).

In spite of all previous animosity, when the dust had settled the national political and economic elite moved quickly in the direction of reconciliation. On July 13 the two former presidential adversaries met. They shared a carefully orchestrated joke in Jakarta's newly-inaugurated Mass Rapid Transportation. Next Prabowo was invited to a dish of the legendary fried rice cooked by Megawati Sukarnoputri, the matriarch of Jokowi's party. Then he accepted the position of Minister of Defence. Though Prabowo diehards were shocked, the reconciliation made a lot of sense. Not only in relation to the sharing of power and the distribution of political posts, common issues in Indonesia's climate of transactional politics (Bourchier, 2015; Mietzner, 2013, 2015, 2016). But also in terms of business interests. Presidential campaigns are tremendously expensive (Aspinall \& Berenschot, 2019). The major share of Prabowo's campaign funds came from the

${ }^{22}$ Adherents of a caliphate reason that democracy is not in line with Allah's ways, but the product of Western politics that marginalizes Islam and restricts Muslims' role in politics. See Mundayat (2019). 
deep pockets of his younger brother, Hashim Djojohadikusumo ${ }^{23}$. An opportunity to retrieve some of that money presented itself. Jokowi announced his plan to relocate the political centre of the country from Jakarta to Kalimantan, to an area in which Hashim has leased most of the land (namely 173.000 ha of the needed $180.000 \mathrm{ha}$ ) (Rahman, Gorbiano, \& Adri, 2019) ${ }^{24}$. The predatory clans of political and economic oligarchs have many common interests, as the film Sexy Killers on Indonesian coal mines revealed ${ }^{25}$. Slater (2018) calls this cartelization, the continued practice of power sharing between opposition and the elected president.

Another process of amalgamation went on between the two camps in which the army had divided itself during the campaign. Both candidates had assured themselves of the support of major military figures. In Jokowi's campaign, the notorious human rights offender Wiranto played a dominant role ${ }^{26}$. Other powerful retired generals supported Prabowo's side. In spite of their differences, the army agrees on two issues: they will never accept to end the impunity they enjoy for any of the human rights offenses they have committed. Secondly, they demand ever more money. With success. As Ghaliya (2019b) reports, the defence sector has managed to get the biggest share of the 2020 state budget, an increase of 16 percent compared to the allocation of 2019.

In the third place fundamentalist Muslim groups managed to build a common platform to promote their programme to slowly impose a sharia-based society. Although most of the fundamentalist Muslim groups voted for Prabowo, this does not mean that they are united. The three most important groups, the (prohibited) HTI, the Islamist party PKS (Partai Keadilan Sosial, Social Justice Party) and the aggressive militia FPI call each other kafir (unbeliever). The alliance of the Islamist parties and organizations with Prabowo and his secular party Gerindra was purely instrumental, based on their aversion to Jokowi.

Islamist parties from both sides, notably the PKS from the Prabowo coalition and the PPP (PartaiPersatuan Pembangunan, United Development Party) that supported Jokowi, joined forces to speed up deliberations on the long-awaited revision of the Criminal Code. This Code hails from the Dutch colonial era. For several decades discussions have been going on to revise $\mathrm{it}^{27}$. A surprise letter on 12 August 2019 from ultra-conservative newly-elected Vice-President Ma'ruf Amin speeded up the process: "God willing, the Criminal Code will be an his-

\footnotetext{
${ }^{23} \mathrm{He}$ is listed number 40 on Forbes 2019 list of wealthiest Indonesians.

${ }^{24}$ This is also the opinion of KharisharKahfi and N. Adri, in their article "Why Jokowi's administration picked two regencies in East Kalimantan to host new capital" in The Jakarta Post of 4 September 2019. https://www.thejakartapost.com/news/2019/09/04/why-jokowis-administration-picked-two-regencie s-in-east-kalimantan-to-host-new-capital.html timber company in the area is called PT International Timber Corporation Indonesia (ITCI) owned by conglomerate Hashim Djojohadikusumo. It is located in Sepaku district in North PenajamPaser, and manages about 173,000 ha of land in total. See also https://coconuts.co/jakarta/news/prabowo-subianto-owns-land-on-site-for-new-capital-city-willingto-give-it-up-gerindra/.

${ }^{25}$ This documentary film was widely shared on social media prior to the elections. See Shahni (2019).

${ }^{26} \mathrm{He}$ was the boss of Prabowo when the latter served in East Timor and during the 1998 unrest.

${ }^{27}$ See Wieringa (2019b) for a chronology.
} 
torical landmark recorded in golden ink as one of the biggest achievements of president Joko Widodo, something previous governments failed to do"28.

Thus encouraged, the House rushed through various controversial bills, in particular the revised Anti-Corruption Law, and concluded deliberations on the revised Criminal Code, while deliberations on the Anti-Sexual Violence Bill that women desperately needed were postponed. The newly re-elected president recommended the revisions of the anti-Corruption Law and agreed to the proposed revisions of the Criminal Code. The Anti-Corruption Law was passed and is widely seen to cripple the Anti-Corruption Commission, which has managed to get numerous national and regional politicians convicted for corruption. The KPK, established in 2003, is understandably hugely unpopular with corrupt politicians, but it is seen as one of the major success stories of the Reform period by the wider public. Under this new law, the KPK loses its independence ${ }^{29}$. The revisions of the Anti-Corruption Law were passed in a few days of mostly closed-door meetings (Ghaliya \& Tehusijarana 2019).

The debates on the revisions of the Criminal Code were likewise rushed through; voting was to be done in the last week of September 2019. The deliberations resulted in several contentious articles. Apart from issues that limit freedom of expression and association, such as articles related to blasphemy, insulting the president and spreading Marxist-Leninist teachings (jail term up to 10 years), the majority of the controversial articles in the revised Criminal Code are related to issues of morality, targeting women and sexual minorities.

Such articles penalize extramarital sex (with a jail term of up to one year) and living together without being married (jail term of up to six months). These articles are "gender-neutral" and directly affect LGBT people, as they are not allowed to marry. Couples who cannot get married because of bureaucratic or religious problems (for instance because one or both partners adhere to a religious belief that is not officially recognized) are also affected. All these articles apply to foreigners as well.

Also to be regulated are pornography (which already has a law of its own, in which LGBT people are deemed to engage in "deviant" sexual practices) and "obscene" acts in public, which is feared to target LGBT people such as MTF transgender persons usually called waria $^{30}$. Worrying too is the prohibition of most forms of abortion (jail term of up to 4 years) and severe limitations put on discussions on family planning, contraception and sexual health. The stipulation that not only spouses and parents can denounce the behaviour prohibited in these articles, but also village heads is equally disturbing. As a member of the drafting committee, Asrul Sani, of the fundamentalist party PPP, explained, "cohabitation results in social damage. The society around the couple can be

${ }^{28}$ Quoted in McBeth (2019). See Fealy (2018) for an analysis of Amin's Islamic politics.

${ }^{29}$ According to various WhatsApp groups I visited, the weakening of the KPK follows a sustained campaign of politicians, supported by the army and Jokowi to frame the KPK as an institution linked to the Taliban. See also Butt (2011).

${ }^{30}$ Waria are MTF transgender people. As it is difficult for them to engage in formal paid work many of them resort to sex work. 
harmed. In Islam, if people commit adultery again and again, the angels do not want to visit 40 houses around the house of the couple ..."31.

Another danger lies in article 2 of the revised Criminal Code which reads that "any living law" will be upheld. It is feared that the discriminatory regional regulations may now be upgraded to the national level, though many of them violate the articles of human rights in the constitution. As it is not further specified what is meant by this phrase and as there is no agreed list of those regulations, this article may be used to criminalize people based on all kinds of patriarchal customary laws and discriminatory regional regulations ${ }^{32}$.

The unprecedented speed with which the parliament acted in its last weeks of office took the human rights movement by surprise. No public consultations were held. And although journalists and activists regularly had been expressing their worries over the proposed revisions of the Anti-Corruption Bill few could anticipate that the final version would be rushed through in September 2019. The major protest against these revisions had come from academics at Gadjah Mada University in Yogyakarta. A lecturer had created the National Academician Alliance WhatsApp group on September 7, but he could no longer access it on September 10. The group had gathered the support of some 2100 academicians nationwide ${ }^{33}$. He declared that his phone number was hacked at a meeting at the university where lecturers, students and anticorruption activists made a declaration that affirmed "UGM Says No to Efforts to Weaken the KPK" (Wahyuni, 2019). This seemingly professional hacking action effectively closed down the group. The following week the Bill was passed into Law.

With the established human rights movement silenced or exhausted from the election campaign, a new group of demonstrators appeared during the last days of September 2019. Tens of thousands university students and pupils of technical high schools (STM, Sekolah Teknik Menengah) took to the streets in Jakarta, and in other major cities all over the country. Their demands focused on the revocation of the just passed revision of the Anti-Corruption Law and the ceasing of the deliberations on the revised Criminal Code, which was due for its final vote the week thereafter. This draft revised Criminal Code is "disastrous not only for women and religious and gender minorities, but for all Indonesians", concluded Andreas Harsono of Human Rights Watch (2019). But the anger of the demonstrators went deeper, relating to their disappointment that the promises of the first years of the Reform period were rolled back by the country's political, security and economic elite. The security forces reacted with characteristic violence, resulting in hundreds of protesters injured, five of whom died. Almost 1500 students were arrested (Arbi, 2019). The students had no success in rolling back the revised Anti-Corruption Law, but they did manage to stall the discussions on the revised Criminal Code.

\footnotetext{
${ }^{31}$ He said that on 16 September 2019, in the parliamentary complex in Senayan (Putri, 2019).

${ }^{32} \mathrm{On}$ regulations discriminating women and LGBT persons see Katjasungkana and Wieringa (2016).

${ }^{33}$ Another report mentions 3000 members from more than 30 universities who signed a petition to protest the revisions in the Anti-Corruption Law (Wijayanto, 2019).
} 


\section{The Perils of Narrow Solidarity in the Human Rights Movement}

Mired in their intense, personalized conflicts, the established human rights movement was unable to build a common platform of demands which they could fight for in their respective camps. During the campaign little attention was paid to issues like the suppression of activists against corruption or the continued stigmatization of the victims and survivors of human rights violations and of the many land and labour conflicts in the nation ${ }^{34}$. The broad consensus in the national political field (on Islam and the character of the nation) trickled down to the culture of the human rights movement, to a narrow form of solidarity with their political leaders. Those who breached this consensus were not regarded as persons who might have a different view on particular topics but as people who somehow had a lower morality; they might become objects of hate speech and personal slander. Though many Jokowers were disappointed by the many promises broken by their hero, they did not seek to find common ground on particular issues with the followers of Prabowo. Likewise Prabowo supporters were unable to reach out to their political adversaries. Neither camp was able to substantially influence the political platform of their own leaders. Instead they engaged in personalized feuds, which weakened their effectiveness as a human rights movement as a whole. Within their bubbles differences of opinion were glossed over; the gaps between the two camps were exaggerated. I argue that if a politics of affinity had been accepted, more similarities of position could have been discovered. Below I provide four illustrations.

\subsection{The International People's Tribunal on the 1965 Mass Crimes against Humanity}

In 2013, in anticipation of the 50 year anniversary of the beginning of Indonesia's genocide, a group of Indonesian human rights activists, exiles living in The Netherlands and academics took the initiative to establish a People's Tribunal on the human rights violations after October 1, 1965. The well-known women's and human rights lawyer Nursyahbani Katjasungkana became the general coordinator. I became the chair of the Foundation International People's Tribunal on Mass Crimes Against Humanity after October 1, 1965 (IPT 1965, 2017). Everybody contributed their time voluntarily. Some of us, particularly Nursyahbani, worked full time and unpaid. The People's Tribunal was held in November 2015 and generated broad media coverage (Wieringa 2018; Wieringa, Melvin, \& Pohlman, 2019).

This successful political and moral initiative was abruptly stopped short when a vicious campaign was waged against Nursyahbani. In 2018 she had accepted a position in Jakarta's Anti-Corruption task force, established by Jakarta's governor Anies Baswedan. This was seen as high treason by the ardent Jokowers/Ahokers of the IPT 1965 team both in Jakarta and in The Netherlands. They

${ }^{34}$ See for instance Heryanto (2019). 
reacted furiously, spouting personal insults, and even managed to make a Dutch journalist take their side in a libellous article in the well-known periodical De Groene $^{35}$. Two weeks later the periodical published an open letter in which the slander against the general coordinator of IPT 1965 was debunked. The journalist had not taken the trouble to verify the many lies whispered into her ears ${ }^{36}$. So justice was done, but great harm was also done. In the bitter exchange of arguments that accompanied the row, IPT 1965 split and lost much of its effectiveness to continue the fight for the rights of the victims/survivors of the 1965 genocide in Indonesia.

\subsection{The Weakening of the Anti-Corruption Commission ${ }^{37}$}

The unprecedented speed with which the parliamentary discussions on the revision of KPK Law 30/2002 on Corruption were rushed through, took the wider human rights movement by surprise, as mentioned above. What factors played a role in the inability to salvage this icon of the Reform Period? I already referred to the securitization of Indonesian society, in which criticism of the president quickly becomes an offense (Bourchier, 2015) ${ }^{38}$. Here I focus on the internal dynamics in the human rights movement.

The debates on reforms of the KPK had been ongoing for some time without much input from social society. Jokowi only invited his supporters to discuss proposed revisions, such as the prominent intellectual and poet Mohamad Goenawan, founder of the magazine Tempo. Conspicuously absent from these discussions were well-known anti-graft activists such as Haris Azhar, coordinator of the major human rights organization KontraS (from 2010 till 2016) and Asfinawati, chair of the YLBHI in Jakarta. Even close associates of the president, such as former chair of the National Human Rights Commission, Ifdhal Khasim, or a founder of the Indonesia Corruption Watch, Teten Masduki, were powerless to protect the KPK. As president of the republic, Jokowi has the power to veto ongoing law revisions. He did not use that prerogative but instead encouraged the parliament to finalize the discussions. The KPK is understandably hugely unpopular with corrupt politicians. Since its inception 72 lawmakers have been prosecuted. It is seen as one of the major success stories of the post-Suharto period by the wider public.

In the final stage the revisions of the Anti-Corruption Law were passed in a few days of mostly closed-door meetings (Ghaliya \& Tehusijarana, 2019). Apparently powerful intra-elite maneuvers including by Jokowi's political patron, Megawati, had prevailed over concerns of the public. Under this new law (Law 19/2019) the KPK loses its independence and its ability to perform sting opera-

\footnotetext{
${ }^{35}$ Issue 28, 12 July 2018.

${ }^{36}$ One of these lies was that Nursyahbani had been offered a position as a judge in the Supreme Court for supporting Prabowo. In reality she is a prominent politician of the PKB (National Awakening Party) which supported Jokowi. She has never been in contact with Prabowo.

${ }^{37}$ See the report on the KPK by Transparency International 2019.

${ }^{38}$ Under the guise of corona, this policy is even strengthened. See

https://forsea.co/southeast-asian-regimes-attack-democracy-on-the-pretext-of-covid-19/.
} 
tions is curtailed.

When Mohamad Goenawan realized Jokowi had supported a move that turned the KPK from an independent agency to a body controlled by the government, he finally criticized the president (Sihalolo, 2020). He joined other intellectuals in demanding the president issue a Presidential Letter (Perppu) to repeal the KPK Law revisions (News Desk The Jakarta Post, 2019b). By then Tempo, which has always been known for its support of Jokowi, had published an edition of (September 12-16, 2019) with its front page featuring a photo of the president's face, against the background of a long Pinocchio-like nose. The caption read "promises remain promises". This belated admission of Jokowi supporters that their hero has not kept the promises with which he won the 2014 elections hampered the effectiveness of the protests of many anti-graft activists who worried about the revisions much earlier. After all, "Jokowi lied" was the main slogan on which Prabowo campaigned and it was difficult for Jokowers to agree to that slogan.

\subsection{The Women's Movement and the Anti-Sexual Violence Bill}

While parliament rushed through the Anti-Corruption Law, and vigorously debated revisions on the Criminal Code, the representatives neglected to discuss the Bill on the Elimination of Sexual Violence, though it had been included in the list of 50 bills to be prioritized in the 2020 national legislation program. The Bill was initiated in 2016, and has been widely supported by the Indonesian women's movement. One of the major actors pushing for the Bill is the National Commission on Violence Against Women (Komnas Perempuan), established after the mass rapes of Chinese women in May $1998^{39}$. The Bill on the Elimination of Sexual Violence aims to prevent all forms of sexual violence; to deal with, protect and restore victims; to take action against perpetrators; and to realize an environment free of sexual violence. The bill includes nine types of sexual violence namely: sexual harassment, sexual exploitation, forced contraception, forced abortion, rape, forced marriage, forced prostitution, sexual slavery, and sexual torture (Pratiwi \& Thalib, 2019).

Since its inception there has been wide pressure from civil society groups in pushing the House of Representatives to pass the bill. Yet their efforts failed. One problem is that this bill is deliberated in a Commission (VIII) which contains a large number of conservative Muslim politicians, as it deals with religion and social affairs. Under increasing pressure to demonstrate one's Muslim credentials, as has been discussed above, it has become difficult for these politicians, even if they see the need to curb sexual violence, to support a bill that was seen to promote premarital sex and homosexuality, although there is nothing in the bill to justify this claim. Another factor is the increasing trend to reject feminism as liberal and western. This anti-feminist discourse flared up by the beginning of

${ }^{39}$ See its website for the latest statistics on violence against women:

https://www.komnasperempuan.go.id/. 
the presidential campaign and negatively affected discussions on the bill. The issue became suddenly a "hot potato", declared Komnas Perempuan commissioner Mariana Amiruddin (CNN Indonesia, 2019b).

The split in the women's movement between adherents of Jokowi and of Prabowo was, I suggest, another factor. This impeded the movement to act decisively and influence the agendas of their respective candidates. Instead of focusing on the one issue, they all agreed on, the passing of the Anti-Sexual Violence Bill, endless quibbles took place among themselves. Sexual violence or gender issues in general never was a priority on Jokowi's agenda, and unfortunately the ardent women Jokowers could not change that. Gerindra, Prabowo's party, on the other hand, focused on poor women, skilfully exploiting the fact that Jokowi never managed to elevate their position. Vice-presidential candidate Sandiaga Uno made frequent visits to markets where he discussed the problems of lowerclass women ${ }^{40}$. He often spoke of these visits, for instance in the TV debates in which both presidential candidates, flanked by their vice-presidential candidates outlined their programmes. The wide support from conservative Muslim groups and parties inhibited the more secular and liberal members of Gerindra from advocating an end to sexual violence. This emak-emak (term for older lower-class women) feminism was criticized by adherents of Jokowi and defended by supporters of Prabowo and in between tempers soared, and the pressure to get the Anti-Sexual Violence Bill passed lost some of its badly needed drive.

\subsection{Criminal Code}

The LGBT community is arguably one of the most oppressed groups in Indonesia. Since the democratic opening in 1998 LGBT people also slowly started organizing (Boellstorff, 2005). But since late 2015 a strong campaign of homophobia took off, initially primarily by academic and political leaders (Katjasungkana \& Wieringa, 2016). Fed by a groundswell of Muslim conservatism calls for the criminalization of homosexuality were increasingly heard (Wieringa 2019a, 2019b). Foreign funding was prohibited and many full-time activists found themselves without income. The proposed revision of the Criminal Code is the latest attempt to criminalize same-sex relations ${ }^{41}$. The LGBT community, haunted and despised, is in no position to act as an independent political factor. They have to rely on the support of others. The women's movement has of old been one of their staunchest allies. Unfortunately some of the LGBT activists, such as AZ (identity withheld), a well-known leader of one of the most prominent LGBT organizations, became paid buzzers for the Jokowi campaign. In vicious postings on social media they denounced anyone they didn't agree with, alienating former strong feminist supporters. With the women's movement internally divided, opposition to the revised Criminal Code was not as strong as it might have been.

\footnotetext{
${ }^{40}$ See for instance https://www.boombastis.com/sandiaga-uno-dicintai-emak-emak/179519. 3 Fakta Ini Buktikan Kalau Sandiaga Uno Dicintai Emak-emak Seluruh Indonesia, undated.

${ }^{41}$ Early 2020 another homophobic bill was introduced, the Family Resilience Bill. But after its introduction it was shelved. See for instance Hartono (2020).
} 
These discussions are not over yet, and criminalization of homosexuality is high on the agenda of conservative politicians.

\subsection{Solidarity at What Cost?}

The four cases discussed above illustrate some of the problems that a narrow interpretation of the concept of solidarity entails. As discussed elsewhere, solidarity can lead to a positive identification with others, to a common identity that allows a collective agency to emerge. But it can also lead to a lack of respect for a diversity of opinion or identity, leading to demonization or the creation of enemy others who do not share the same views. Sameness then becomes an imperative, instead of equality with its inherent possibility of dissent and respect for otherness (Conway, 2003; Levitas, 1995). These problems appeared in the Indonesian situation as well. Prioritizing the agendas of their own presidential candidates, members of both sides at times demonized members of the other side. In the process, the commonality of their interests tended to get lost. Support for the Anti-Corruption Commission, justice for the victims of the many human rights violations the Indonesian state committed, an end to sexual violence and women's oppression, respect for LGBT persons and so many other issues need unity, not fractured groups.

The concept of affinity comes in useful here. Collaborating on the basis of affinity rather than on solidarity entails that people may harbour different views on various issues, but decide to pursue certain common goals (Wieringa, 2009). This requires a politics of coalition building on the basis of shared interests. These may include the above mentioned issues as well as the repeal or at least softening of the harsh laws that are used to stifle their movements, the blasphemy and the draconian law on Information and Electronic Transactions. These laws are used to curb freedom of expression, thought, conscience and belief and have denied sexual and religious minorities their rights.

In spite of the courageous efforts of the numerous activists that make up the wider human rights movement, the split caused by the narrow interpretation of solidarity (those who are not 100 percent with us are our enemies) between Jokowers and ardent supporters of Prabowo, weakened and exhausted major parts of the human rights movement.

\section{Conclusion}

This article discusses the internal dynamics of various groups within the wider human rights movement during and immediately after the 2019 presidential campaign. The starting point was the question of why they could not be more effective when parliament in its last weeks of session rushed through controversial legislation, weakening the popular and effective Anti-Corruption Committee. Only by bloody mass demonstrations of generally young students, voting on the revised draft of the Criminal Code could be prevented. These revisions entailed repressive and discriminatory articles on gender and sexual relations. 
It is clear that external factors played a major role. The securitization of society, exemplified by the language of treason used by the security forces, has led to the arrest of critics of the president and the silencing of dissent. Indonesia has long been sliding into an illiberal form of democracy, after the hopeful first years of the end of the New Order in 1998. Draconian laws such as the ITE and blasphemy laws are widely used. The conservative turn of society inspired by decades of dakwah (proselytization), and the growing influence of at times militant Muslim groups has prepared the groundwork for the pressure to curb women's rights, criminalize homosexuality and ignore the demand of the women's movement for a law to end sexual violence. Debates on these issues have become muffled in the broad but vague national consensus on the importance of Islam and the nation. As Muslim groups see communism as their arch enemy, attempts to support the victims of the post-October 1965 genocide and to lift the stigma associated with the victims and survivors of this genocide are vehemently thwarted. These issues have been discussed elsewhere.

Less attention has been focused on the internal dynamics of the human rights movement. Prior to and during the 2019 presidential campaign they became divided into two antagonistic groups. Rather than focusing on their own shared pressing concerns and preserving their badly needed unity in the face of the external factors outlined above, they prioritized the agendas of their preferential candidate. Some of them engaged in abusive behaviour, demonizing their former allies, in the name of a narrow inner-group solidarity. I suggest this contributed to their enervation in relation to the post-election doings in parliament.

\section{Conflicts of Interest}

The author declares no conflicts of interest regarding the publication of this paper.

\section{References}

Alisjahbana, T. (2014). What Really Happened in Kraras? The Jakarta Post, 21 January. https://www.thejakartapost.com/news/2014/01/21/what-really-happened-kraras.html

Antlöv, H., \& Cederroth, S. (2004). Elections in Indonesia: The New Order and Beyond. Nordic Institute of Asian Studies, Monograph Series 88. London: Routledge Curzon.

Arbi, I. A. (2019). Student Protest Aftermath: Family Questions Police Account of Protestor's Cause of Death. The Jakarta Post, 7 October. https://www.thejakartapost.com/news/2019/10/07/student-protest-aftermath-family-q uestions-police-account-of-protestors-cause-of-death.html

Arismunandar, S. (Ed.) (2019). NKRI Bersyariahatau Ruang Public yang Manusiawi: Tanggapan 21 Pakarterhadap Gagasan Denny JA. Jakarta: CerahBudaya Indonesia.

Aspinall, E., \& Berenschot, W. (2019). Democracy for Sale: Elections, Clientelism, and the State in Indonesia. Ithaca, NY and London: Cornell University Press. https://doi.org/10.7591/9781501732997

Aspinall, E., \& Mietzner, M. (Eds.) (2010). Problems of Democratisation in Indonesia: Elections, Institutions and Society. Singapore: ISEAS.

https://doi.org/10.1355/9789814279918 
Bachari, A. D. (2019). Analysis of Form and Theme of Hate Speech Against President Joko Widodo on Social Media: A Forensic Linguistic Study. In Advances in Social Science, Education and Humanities Research. Proceedings of the Second Conference on Language, Literature, Education, and Culture (ICOLLITE 2018) (pp. 223-226). Amsterdam: Atlantis Press. https://doi.org/10.2991/icollite-18.2019.49

Bakker, L. (2016). Organised Violence and the State: Evolving Vigilantism in Indonesia. Bijdragen tot de Taal-, Land-en Volkenkunde, 172, 249-277. https://doi.org/10.1163/22134379-17202001

Boellstorff, T. (2005). The Gay Archipelago: Sexuality and Nation in Indonesia. Princeton, NJ: Princeton University Press. https://doi.org/10.1515/9781400844050

Bourchier, D. (2015). Illiberal Democracy in Indonesia: The Ideology of the Family State. London and New York: Routledge. https://doi.org/10.4324/9780203379721

Bourchier, D. (2019). Two Decades of Ideological Contestation in Indonesia: From Democratic Cosmopolitanism to Religious Nationalism. Journal of Contemporary Asia, 49, 713-733. https://doi.org/10.1080/00472336.2019.1590620

Buehler, M. (2016). The Politics of Shari'a Law: Islamic Activists and the State in Democratizing Indonesia. Cambridge: Cambridge University Press. https://doi.org/10.1017/CBO9781316417843

Butt, S. (2011). Anti-Corruption Reform in Indonesia: An Obituary? Bulletin of Indonesian Economic Studies, 47, 381-394. https://doi.org/10.1080/00074918.2011.619051

Butt, S. (2018). Religious Conservatism, Islamic Criminal Law and the Judiciary in Indonesia: A Tale of Three Courts. The Journal of Legal Pluralism and Unofficial Law, 50, 402-434. https://doi.org/10.1080/07329113.2018.1532025

Chan, F. (2018). Identity Politics rears its Head again in Indonesia. Straits Times, 8 December.

https://www.straitstimes.com/asia/se-asia/identity-politics-rears-its-head-again-in-ind onesia

CNN Indonesia (2019b). RUU PKS Mendadak Jadi "Bola Panas" saat Pilpres. 7 February. https://www.cnnindonesia.com/nasional/20190207113653-32-367091/ruu-pks-mendad ak-jadi-bola-panas-saat-pilpres

Coconuts Jakarta (2019). Women Said Jokowi Ban Call Prayer: Legalize Gay Marriage. https://coconuts.co/jakarta/news/3.women-said-jokowi-ban-call-prayer-legalize-gay-m arriage-named-hate-speech-suspects-police/

Conway, J. (2003). Civil Resistance and the "Diversity of Tactics" in the Anti-Globalization Movement: Problems of Violence, Silence, and Solidarity in Activist Politics. Osgoode Hall L.J. Hein Online.

https://heinonline.org/HOL/LandingPage?handle=hein.journals/ohlj41\&div=30\&id=\& page

Cribb, R. (Ed.) (1991). The Indonesian Killings of 1965-1966. Studies from Java and Bali. Melbourne: Monash Asia Institute.

Duile, T., \& Bens, J. (2017). Indonesia and the "Conflictual Consensus": A Discursive Perspective on Indonesian Democracy. Critical Asian Studies, 49, 139-162. https://doi.org/10.1080/14672715.2017.1295358

Fauzi, M. L. (2016). Women in Local Politics: The Byelaws on Prostitution in Bantul. In K. Van Dijk, \& N. J. G. Kaptein (Eds.), Islam, Politics and Change: The Indonesian Experience after the Fall of Suharto (pp. 195-217). Leiden: Leiden University Press.

Fealy, G. (2018). Ma'ruf Amin: Jokowi’s Islamic Defender or Deadweight? New Mandala. https://www.newmandala.org/maruf-amin-jokowis-islamic-defender-deadweight/ 
Gelora News (2020). Eks Penulis Seword: Kakak Pembina Perintahkan Puja-puji Jokowi, Jelekkan Ulama dan Ajaran Islam.

https://www.gelora.co/2020/04/eks-penulis-seword-kaka-pembina.html

Ghaliya, G. (2019a). Prabowo Supporters to Hit Streets on May 22 Despite Terrorism Alert. The Jakarta Post, 19 May.

https://www.thejakartapost.com/news/2019/05/19/prabowo-supporters-to-hit-streets-o n-may-22-despite-terrorism-alert.html

Ghaliya, G. (2019b). Defense Gets Biggest Budget. The Jakarta Post, 23 August. https://www.thejakartapost.com/news/2019/08/29/who-owns-land-in-new-capital-city. $\underline{\mathrm{html}}$

Ghaliya, G., \& Tehusijarana, K. M. (2019). House Declaws KPK in Dubious Process. The Jakarta Post, 18 September.

https://www.thejakartapost.com/news/2019/09/18/house-declaws-kpk-in-dubious-proc ess.html

Gibran, K. (2017). Apa Benar Seword Sebarkan Hoax dan Dipelihara Istana. https://www.kompasiana.com/gibranisme93/59d48c6e

Hadiz, V. R. (2000). Retrieving the Past for the Future? Indonesia and the New Order Legacy. Asian Journal of Social Science, 28, 11-33. https://doi.org/10.1163/030382400X00037

Hadiz, V. R. (2017). Indonesia's Year of Democratic Setbacks: Towards a New Phase of Deepening Illiberalism? Bulletin of Indonesian Economic Studies, 53, 261-278. https://doi.org/10.1080/00074918.2017.1410311

Hartono, L. V. (2020). Does Indonesia Really Need a Family Resilience Bill? https://www.thejakartapost.com/news/2020/02/25/does-indonesia-really-need-a-family -resilience-bill.html

Hermawan, A. (2020). The Curious Case of Ravio Patra: Why Indonesian Cyberspace Is a Dystopian Nightmare.

https://www.thejakartapost.com/academia/2020/04/24/the-curious-case-of-ravio-patra -why-indonesian-cyberspace-is-a-dystopian-nightmare.html

Heryanto, A. (2006). State Terrorism and Political Identity in Indonesia: Fatally Belonging. London: Routledge. https://doi.org/10.4324/9780203099827

Heryanto, A. (2019). Yang Terabaikan Dari Rekonsiliasi. Tirto, 17 July. https://tirto.id/yang-terabaikan-dari-rekonsiliasi

Human Rights Watch (2019). Indonesia-Draft-Criminal-Code-Disastrous. https://www.hrw.org/news/2019/09/18/indonesia-draft-criminal-code-disastrous

IPT 1965 (2017). Final Report of the International People's Tribunal on Crimes against Humanity in Indonesia 1965. Bandung: Ultimus.

Jorgensen, D. L. (2015). Emerging Trends in the Social and Behavioral Sciences: An Interdisciplinary, Searchable, and Linkable Resource. Wiley Online Library, 15 May.

Katjasungkana, N., \& Wieringa, S. E. (2016). Creeping Criminalisation: Mapping of Indonesia's National Laws and Regional Regulations that Violate Human Rights of Women and LGBTIQ People. New York: Outright.

https://www.outrightinternational.org/sites/default/files/CreepingCriminalisation-eng. pdf

Kersten, C. (2015). Islam in Indonesia: The Contest for Society, Ideas and Values. London: Hurst \& Company. https://doi.org/10.1093/acprof:oso/9780190247775.001.0001

Levitas, R. (1995). We: Problems in Identity, Solidarity and Difference. History of the Human Sciences, 8, 89-105. https://doi.org/10.1177/095269519500800305 
McBeth, J. (2019). Man with a Plan to Make Indonesia More Islamic, Vice-President Ma'ruf Amin behind Retrograde Criminal Law Bill That Has Sparked Violent Protests. Asiatimes.

https://www.asiatimes.com/2019/09/article/man-with-a-plan-to-make-indonesia-more -islamic/

McGregor, K., \& Setiawan, K. (2019). Shifting from International to "Indonesian" Justice Measures: Two Decades of Addressing Past Human Rights Violations. Journal of Contemporary Asia, 49, 837-861. https://doi.org/10.1080/00472336.2019.1584636

McNabb, D. E. (2015). Research Methods for Political Science: Quantitative and Qualitative Methods. London and New York: Routledge. https://doi.org/10.4324/9781315701141

Melvin, J. (2018). The Army and the Indonesian Genocide: Mechanics of Mass Murder. London and New York: Routledge. https://doi.org/10.4324/9781351273329

Mietzner, M. (2013). Money, Power, and Ideology: Political Parties in Post-Authoritarian Indonesia. Singapore: NUS Press. https://doi.org/10.2307/j.ctv1nthsj

Mietzner, M. (2015). Reinventing Asian Populism: Jokowi's Rise, Democracy, and Political Contestation in Indonesia. Policy Studies, No. 72, 74.

https://www.eastwestcenter.org/publications/reinventing-asian-populism-jokowis-risedemocracy-and-political-contestation-in

Mietzner, M. (2016). Coercing Loyalty: Coalitional Presidentialism and Party Politics in Jokowi's Indonesia. Contemporary Southeast Asia, 38, 209-232. https://doi.org/10.1355/cs38-2b

Mundayat, A. A. (2019). Pancasila, Democracy vs "Khilafah": Challenge for Indonesia. The Jakarta Post, 2 August.

https://www.thejakartapost.com/academia/2019/08/02/pancasila-democracy-vs-khilafa h-challenge-for-indonesia.html

Nathalia, T. (2019). Fourth Presidential Candidate Debate Marked by Slow Pace. Jakarta Globe, 1 April.

Nawab, M., Osman, M., \& Waikar, P. (2018). Fear and Loathing: Uncivil Islamism and Indonesia's Anti-Ahok Movement. Indonesia, 106, 89-106. https://doi.org/10.1353/ind.2018.0016

News Desk The Jakarta Post (2018). Jokowi to Meet Kamisan Protesters for First Time. https://www.thejakartapost.com/news/2018/05/31/jokowi-to-meet-kamisan-protestersfor-first-time.html

News Desk The Jakarta Post (2019a). Ahmad Dhani Walks Free after Serving 11 Months for Hate Speech.

https://www.thejakartapost.com/news/2019/12/30/ahmad-dhani-walks-free-after-servi ng-11-months-for-hate-speech.html

News Desk The Jakarta Post (2019b). Senior Public Figures Renew Calls for Repeal of KPK Law Revisions. The Jakarta Post, 10 April. https://www.thejakartapost.com/news/2019/10/04/senior-public-figures-renew-calls-fo r-repeal-of-kpk-law-revisions.html

Nyman, M. (2006). Democratising Indonesia: The Challenges of Civil Society in the Era of Reformasi. Copenhagen: NIAS Press.

Pratiwi, A. M., \& Thalib, N. (2019). The Struggle to Pass Anti-sexual Violence Bill in Indonesia.

https://magdalene.co/story/the-struggle-to-pass-anti-sexual-violence-bill-in-indonesia

Putri, B. U. (2019). Pasal Kumpul Kebo di RKUHP Disepakati, Pelapor Bisa Kepala Desa. 
Tempo, 16 September.

https://nasional.tempo.co/read/1248469/pasal-kumpul-kebo-di-rkuhp-disepakati-pelap or-bisa-kepala-desa

Raditya. I. N. (2019). Sejarah Tim Mawar, PenculikanAktivis'98, \& Keterlibatan Prabowo. Tirto, 3 March. https://tirto.id/sejarah-tim-mawar-penculikan-aktivis-98-keterlibatan-prabowo

Rahman, R., Gorbiano, M. I., \& Adri, N. (2019). Who Owns Land in New Capital City. https://www.thejakartapost.com/news/2019/08/29/who-owns-land-in-new-capital-city. $\underline{\mathrm{html}}$

Robinson, G. (2018). The Killing Season: A History of the Indonesian Massacres, 1965-1966. Princeton, NJ: Princeton University Press. https://doi.org/10.1515/9781400888863

Roosa, J. (2006). Pretext for Mass Murder: The September 30th Movement and Suharto's Coup d'État in Indonesia. Madison, WI: University of Wisconsin Press.

Sapiie, M. A. (2019). Prabowo's Claim of Victory Baseless, Court Says. The Jakarta Post, 27 June.

https://www.thejakartapost.com/news/2019/06/27/prabowos-claim-of-victory-baselesscourt-says.html

Sapiie, M. A., \& Ramadhani, N. F. (2019). Seven Key Moments in First Presidential Debate. The Jakarta Post, 18 January.

https://www.thejakartapost.com/news/2019/01/18/seven-key-moments-in-first-preside ntial-debate.html

Shahni, D. (2019). Documentary Film Sexy Killers Probes Indonesian Candidates' Ties to Big Coal.

https://www.eco-business.com/videos/documentary-film-sexy-killers-probes-indonesia n-candidates-ties-to-big-coal

Sihalolo, M. R. (2020). Mengejutkan, Goenawan Mohamad Tiba-tiba Kritik Rezim Jokowi. Tajdid, 23 January.

https://tajdid.id/2020/01/23/mengejutkan-goenawan-mohamad-tiba-tiba-kritik-rezim-j okowi/

SIP (1999). Catatan perjalanan Suara Ibu Peduli. Jakarta: Yayasan Jurnal Perempuan.

Slater, D. (2018). Party Cartelization, Indonesian-Style: Presidential Power-Sharing and the Contingency of Democratic Opposition. Journal of East Asian Studies, 18, 23-46. https://doi.org/10.1017/jea.2017.26

Strick, B., \& Syavira, F. (2019). Papua Unrest: Social Media Bots "Skewing the Narrative". BBC News, 11 October. https://www.bbc.com/news/world-asia-49983667

Sugiharti, S. (2018). Watch Your Remarks in Virtual Space. The Jakarta Post, 6 August.

Syakriah, A. (2019). Human Rights Concerns Arise after Jokowi-Prabowo Meeting. The Jakarta Post, 16 July.

https://www.thejakartapost.com/news/2019/07/15/human-rights-concerns-arise-after-j okowi-prabowo-meeting.html

Tehusijarana, K. M. (2019). There Will Be No One to Worship You: Supporter Stokes Fear of Godless Society If Prabowo Loses Election.

https://www.thejakartapost.com/news/2019/02/24/there-will-be-no-one-to-worship-yo u-supporter-stokes-fear-of-godless-society-if-prabowo-loses-election.html

Tim Detikcom (2019). Syariat Dikaji Pemerintah, FPI Bicara NKRI Bersyariah. https://news.detik.com/berita/d-4650552/syariat-dikaji-pemerintah-fpi-bicara-nkri-ber syariah 
Tribunnews (2019). Sick of Slander, Hoaxes and Identity Politics, Millennials Threaten Vote Boycott. 16 January.

http://www.tribunnews.com/nasional/2019/01/16/pilpres-2019-anak-millenial-pilih-go lput

Tsutsui, K., \& Wotipka, C. M. (2004). Global Civil Society and the International Human Rights Movement: Citizen Participation in Human Rights International Nongovernmental Organizations. Social Forces, 83, 587-620. https://doi.org/10.1353/sof.2005.0022

Van Dijk, K., \& Kaptein, N. J. G. (Eds.) (2016). Islam, Politics and Change: The Indonesian Experience after the Fall of Suharto. Leiden: Leiden University Press. https://doi.org/10.26530/OAPEN_605451

Wadipalapa, R. P. (2019). Commemorating 1965 in Election Year: New Regime, Old Formula. The Jakarta Post, 8 October.

https://www.thejakartapost.com/academia/2019/10/08/commemorating-1965-in-electi on-year-new-regime-old-formula.html

Wahyuni, S. (2019). UGM Lecturer Phone Number Allegedly Hacked after Forming Group Rejecting KPK Law Revision. The Jakarta Post, 15 September.

https://www.thejakartapost.com/news/2019/09/15/ugm-lecturer-phone-number-allege dly-hacked-after-forming-group-rejecting-kpk-law-revision.html

Wibisono, A. A. (2018). Hizbut Tahrir in Indonesia: Riding the Wave of the Islamization Agenda. Middle East Institute, 27 February 2018.

https://www.mei.edu/publications/hizbut-tahrir-indonesia-riding-wave-islamization-a genda

Wieringa S. E. (2003). The Birth of the New Order State in Indonesia: Sexual Politics and Nationalism. Journal of Women's History, 15, 70-91.

https://doi.org/10.1353/jowh.2003.0039

Wieringa, S. E. (2002). Sexual Politics in Indonesia. London: Palgrave Macmillan. https://doi.org/10.1057/9781403919922

Wieringa, S. E. (2009). From Solidarity to Affinity and Feminist Communal Identities. In G. Dütting, W. Harcourt, K. Lohmann, L. McDevitt-Pugh, J. Semeniuk, \& S. Wieringa (Eds.), The European Feminist Forum: A Herstory (2004-2008) (pp. 29-39). Amsterdam: Institute for Women's History.

Wieringa, S. E. (2018). Chapter 5. The International People's Tribunal on 1965 Crimes Against Humanity in Indonesia: An Anthropological Perspective. In A. Byrnes, \& G. Simm (Eds.), People's Tribunals and International Law (pp. 107-133). Cambridge: Cambridge University Press. https://doi.org/10.1017/9781108368360.006

Wieringa, S. E. (2019a). Is the Recent Wave of Homophobia Unexpected? In G. Fealy, \& R. Ricci (Eds.), Contentious Belonging: The Place of Minorities in Indonesia (pp. 113-133). Canberra: ANU Update Series. https://doi.org/10.1355/9789814843478-011

Wieringa, S. E. (2019b). Criminalisation of Homosexuality in Indonesia: The Role of the Constitution and Civil Society. Australian Journal of Asian Law, 20, Article 17.

Wieringa, S. E., \& Katjasungkana, N. (2018). Propaganda and the Genocide in Indonesia: Imagined Evil. New York: Routledge. https://doi.org/10.4324/9780429440243

Wieringa, S. E., Melvin, J., \& Pohlman, A. (Eds.) (2019). The International People's Tribunal for 1965 and the Indonesian Genocide. New York and London: Routledge. https://doi.org/10.4324/9780429427763

Wijayanto (2019). Nationwide Student Marches: A Moral Force Despite the Odds. The Jakarta Post, 28 September.

https://www.thejakartapost.com/academia/2019/09/28/nationwide-student-marches-a$\underline{\text { moral-force-despite-the-odds.html }}$ 
Wilson, C. (2015a). Illiberal Democracy and Violent Conflict in Contemporary Indonesia. Journal Democratization, 22, 1317-1337.

https://doi.org/10.1080/13510347.2014.949680

Wilson, I. (2010). The Rise and Fall of Political Gangsters in Indonesian Democracy. In E. Aspinall, \& M. Mietzner (Eds.), Problems of Democratisation in Indonesia: Elections, Institutions and Society (pp. 199-219). Singapore: ISEAS.

https://doi.org/10.1355/9789814279918-015

Wilson, I. D. (2015b). The Politics of Protection Rackets in Post-New Order Indonesia: Coercive Capital, Authority and Street Politics. London and New York: Routledge. https://doi.org/10.4324/9780203799192 